Jelena Lamovec ${ }^{1 *}$, Ivana Mladenović ${ }^{\text {, Vesna Jović }}$, Vesna Radojević, ${ }^{2}$ Stevo Jaćimovski ${ }^{3}$, Goran Jovanov ${ }^{3}$

${ }^{1}$ University of Belgrade, Institute of Chemistry, Technology and Metallurgy, Center for Microelectronic Technologies, Belgrade, Serbia, ${ }^{2}$ University of Belgrade, Faculty of Technology and Metallurgy, Belgrade, Serbia, ${ }^{3}$ The Academy of Criminalistic and Police Studies, Belgrade-Zemun, Serbia
Scientific paper

ISSN 0351-9465, E-ISSN 2466-2585

UDC:669.248.058:620.5/.6

doi:10.5937/ZasMat1803394L

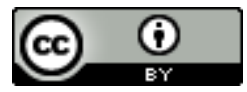

Zastita Materijala 59 (3)

394 - 400 (2018)

\title{
Obtaining and characterization of multilayer nickel thin films electrodeposited with the assistance of ultrasonic agitation
}

\begin{abstract}
Multilayer composite structures of electrodeposited Ni films on polycrystalline copper substrates were fabricated with the assistance of ultrasonic agitation. Alternate ordinary and ultrasonicassisted electrodeposition of Ni layers allowed the formation of laminated films. The adhesion and hardness properties were characterized using bidirectional bending test and Vickers microhardness test with different loads. Dependence of composite microhardness and film adhesion on layer thickness was investigated. It was confirmed that densified parallel interfaces give rise to high hardness and strength of composites. Model of Korsunsky was chosen and applied to experimental data for obtaining the film hardness and model of Chen-Gao was applied for the adhesion evaluation. Compared with the conventional electrodeposited Ni films, the mechanical properties of the ultrasonic-assisted multilayer $\mathrm{Ni}$ films are improved. The microhardness and adhesion of the films are enhanced by introduction of ultrasound and by reducing the layer thickness in the film.
\end{abstract}

Keywords: composite hardness, Ni electrodeposition, ultrasonic agitation, adhesion, multilayers

\section{INTRODUCTION}

Nickel and its alloys are well-known and widely used materials for different industrial applications. Compared with other materials, they possess better corrosion resistance, a range of special electronic and magnetic properties and more toughness and strength at different temperature regimes. Good mechanical properties are critical for mechanical integrity of devices.

In its monocrystalline form, nickel may be considered as a soft material with a small ability to resist deformations. Conventional polycrystalline $\mathrm{Ni}$ has a grain size in the micron range and much better mechanical properties compared to monocrystalline $\mathrm{Ni}$, due to grain boundary hardening [1].

Electrochemical deposition or electro-deposition (ED) is a technique that gives the possibility

\footnotetext{
${ }^{*}$ Corresponding author: Jelena Lamovec

E-mail: jejal@nanosys.intm.bg.ac.rs

Paper received: 29. 01. 2018.

Paper accepted: 25. 02. 2018.

Paper is available on the website:

www.idk.org.rs/journal
}

of obtaining the nanostructured materials with a grain size of less than $100 \mathrm{~nm}$. By controlling the grain size and microstructure, metals can be strengthened and hardened with little loss of ductility. These materials exhibit unique features because of the large surface area-to- volume ratio [2-4].

The nanostructured $\mathrm{Ni}$ obtained by electrochemical deposition has good mechanical properties, such as high yield strength, lower friction coefficient and wear ratings, high hardness values and better corrosion resistance compared with nickel with a standard grain size $[3,4]$.

Introduction of ultrasound into electrochemical deposition may lead to improved microstructural and mechanical properties of deposited films such as increased brightness and hardness, better adhesion to the substrate, a finer grain size, reduced internal stress and porosity and good wear resistance $[5,6]$.

Thin monolayer or multilayer film structures are often used in fabrication of different devices. In multilayer films, the composition of any monolayer is different from that of its adjacent layers. The ultrasonic agitation may be used for obtaining the multilayer film because it gives the possibility to 
modify the microstructure of chosen film layers $[7$, 8].

Thin films are usually grown on substrates and such structures may be considered as the composite systems. Indentation testing is a known and reliable test method for evaluation of composite systems and films mechanical characteristics. During hardness determination of thin films by indentation methods, the influence of the substrate must be taken into account. The measured response of the composite system is socalled "the composite hardness" and it is a complex value depending on the ratio between film thickness and indentation depth and structural and mechanical properties of both the film and the substrate.

Microhardness measurement together with using a bidirectional bend technique offer a significant tool for assessment of electrodeposited thin films adhesion to substrates [9-11].

\section{Models for evaluation the film hardness and adhesion from the composite hardness values}

According to descriptive model of Korsunsky et al. [12], the total-work-of indentation during a hardness test is composed of two parts: the plastic work of deformation in the substrate and the deformation and/or fracture energy in the film. The composite hardness, $H_{C}$, according to this model is given by Eq. (1):

$$
H_{C}=H_{S}+\left[\frac{1}{1+k^{\prime} \cdot\left(d^{2} / t\right)}\right] \cdot\left(H_{F}-H_{S}\right) ; \quad k^{\prime}=\frac{k}{49 \cdot t}
$$

where $k^{\prime}$ represents a dimensionless material parameter related to the composite response mode to indentation, $d$ is indent diagonal and $t$ is the thickness of the film.

This model does not allow calculating the film hardness for each measured indentation diagonal i.e. from the individual measurements of composite hardness. The magnitude of $k$ is determined simultaneously from the experimental measurements of the composite hardness.

Model of Chen - Gao [13] was employed to evaluate and compare the adhesion of $\mathrm{Ni}$ films electrodeposited on $\mathrm{Cu}$ substrates. The model is based on the so-called function of indentation depth weight factor which describes the local hardness contribution to overall composite hardness. The composite hardness $H_{C}$ of the film/substrate system in its simplified form is expressed by Eq.(2):

$$
H_{c}=H_{s}+\left[\frac{(m+1) \cdot t}{m \cdot b \cdot D}\right] \cdot\left(H_{F}-H_{s}\right)
$$

where $H_{S}$ and $H_{F}$ are the hardness of the substrate and the film respectively, $t$ is the film thickness, $D$ is the indentation depth, $b$ is the critical reduced depth (the ratio between the radius of the plastic zone beneath the indentation and the indentation depth) and $m$ is the power index. For this system, the appropriate value for the power index $m$ is found to be 1.2 for a hard film on a soft substrate. Introducing the diagonal $d$ of the indentation with $d=7 D$, for a Vickers indentation test and $\Delta H=H_{S}$ $H_{C}$, Eq. (2) can be organised as Eq. (3):

$$
\Delta H=\left[\frac{7 \cdot(m+1) \cdot\left(H_{S}-H_{F}\right)}{m \cdot b}\right] \cdot\left(t_{d}\right)
$$

The critical reduced depth, $b$, can be then calculated by using Eq.(3), with experimental values of $H_{C}, H_{F}, t$ and $d$.

\section{EXPERIMENTAL PROCEDURE}

\subsection{Preparation of the substrates and films}

A sheet of cold-rolled polycrystalline copper was employed as the substrate material. The samples with dimensions $50 \mathrm{~mm} \times 10 \mathrm{~mm} \times 0.125$ $\mathrm{mm}$ were cut and mechanically and chemically polished in acidic solution $\left(\mathrm{HNO}_{3}: \mathrm{H}_{3} \mathrm{PO}_{4}: \mathrm{CH}_{3} \mathrm{COOH}\right.$ $=4: 11: 5$ vol $\%$ ).

Electrochemical deposition of nickel was performed under the DC - galvanostatic mode, without and with the assistance of agitation in ultrasonic bath $(40 \mathrm{kHz})$. The composition of the nickel sulphamate electrolyte and the deposition parameters are given in Table 1.

\section{Table 1. Composition of the electrolyte and the deposition parameters}

Tabela 1. Sastav elektrolita i parametara depozicije

\begin{tabular}{|l|c|}
\hline $\mathrm{Ni}\left(\mathrm{NH}_{2} \mathrm{SO}_{3}\right)_{2} \cdot 4 \mathrm{H}_{2} \mathrm{O}$ & $300 \mathrm{~g} / \mathrm{l}$ \\
\hline $\mathrm{NiCl}_{2} \cdot 6 \mathrm{H}_{2} \mathrm{O}$ & $30 \mathrm{~g} / \mathrm{l}$ \\
\hline $\mathrm{H}_{3} \mathrm{BO}_{3}$ & $30 \mathrm{~g} / \mathrm{l}$ \\
\hline Saccharine & $1 \mathrm{~g} / \mathrm{l}$ \\
\hline $\mathrm{pH}$ & $4.0-4.4$ \\
\hline Temperature & $50^{\circ} \mathrm{C}$ \\
\hline Current density & $50 \mathrm{~mA} / \mathrm{cm}^{2}$ \\
\hline
\end{tabular}

Projected thickness of deposited films was determined according to the defined deposition area and the current density value. Total thickness of all the films was $10 \mu \mathrm{m}$. First, two monolayer $\mathrm{Ni}$ films were electrodeposited on copper substrates under the same conditions with and without ultrasonic agitation. The multilayer $\mathrm{Ni}$ films were then obtained by alternate deposition of ordinary (O-Ni) and ultrasonic-assisted nickel layers (U-Ni) 
for different deposition times for one layer $(1 \mathrm{~min}$, $30 \mathrm{~s}$ and $15 \mathrm{~s}$ ) and constant film thickness.

\subsection{Microstructure analysis}

Observation of microstructure of the substrate and films was performed by optical microscopy. Cross-section of the $25 \mu \mathrm{m}$-thick multilayer O-Ni/U$\mathrm{Ni}$ film was prepared by cutting the sample vertically to the surface. After mechanical polishing, the sample was etched in acidic solution $\mathrm{HNO}_{3}$ (konc.): $\mathrm{CH}_{3} \mathrm{COOH}$ (glac.) $=1: 1$ for $20 \mathrm{~s}$, followed by etching in $\mathrm{HCl}$ (konc.) for 1.5 hour [14].

\subsection{Microindentation test}

The mechanical properties of the mono and multilayer $\mathrm{Ni}$ film on copper substrate composite systems were characterized using Vickers microindenter "Leitz, Kleinharteprufer DURIMET I" with loads ranging from $0.098 \mathrm{~N}$ up to $0.98 \mathrm{~N}$. At each load, three indentations were made and six indentation diagonals were measured, from which the average composite hardness value could be calculated. The experimental results were fitted with GnuPlot (http://www.gnuplot.info/).

\subsection{Assessment of adhesion}

The adhesion of multilayer Ni films to copper substrate was estimated by a bidirectional bend method. The moment when the film under strain began to detach from the substrate is related to the crytical cycle number of the sample and it was the criterion for the film adhesion assessment. The bending structure was prepared and test conditions were adopted according to work of Niu et al. [7].

\section{RESULTS AND DISCUSSION}

\subsection{Microstructural properties of the Cu substrate and multilayer ED Ni films}

Optical image of the polycrystalline $\mathrm{Cu}$ supstrate after revealing the microstructure is given on Fig. 1(a).The average grain size about few microns is observed. This material belongs to the class of soft materials.

Optical image of the transverse cross-section of multilayer U-Ni/O-Ni film is shown on Fig. 1(b). The multilyer structure of the film is clearly visible. The bright ones are the $\mathrm{Ni}$ layers deposited with ultrasonic assistance (U-Ni) and the dark ones are the ordinary $\mathrm{Ni}$ layers $(\mathrm{O}-\mathrm{Ni})$. It is considered that the grains of the U-Ni layer grow preferentially in the manner parallel to the substrate surface unlike the O-Ni layer, with columnar growth vertical to the substrate surface $[7,8]$.

\subsection{Composite and film hardness}

Load-independent microhardness of the copper substrate was calculated according to Proportional Specimen Resistance (PSR) model as $H_{S}=0.37$ GPa $[15,16]$.
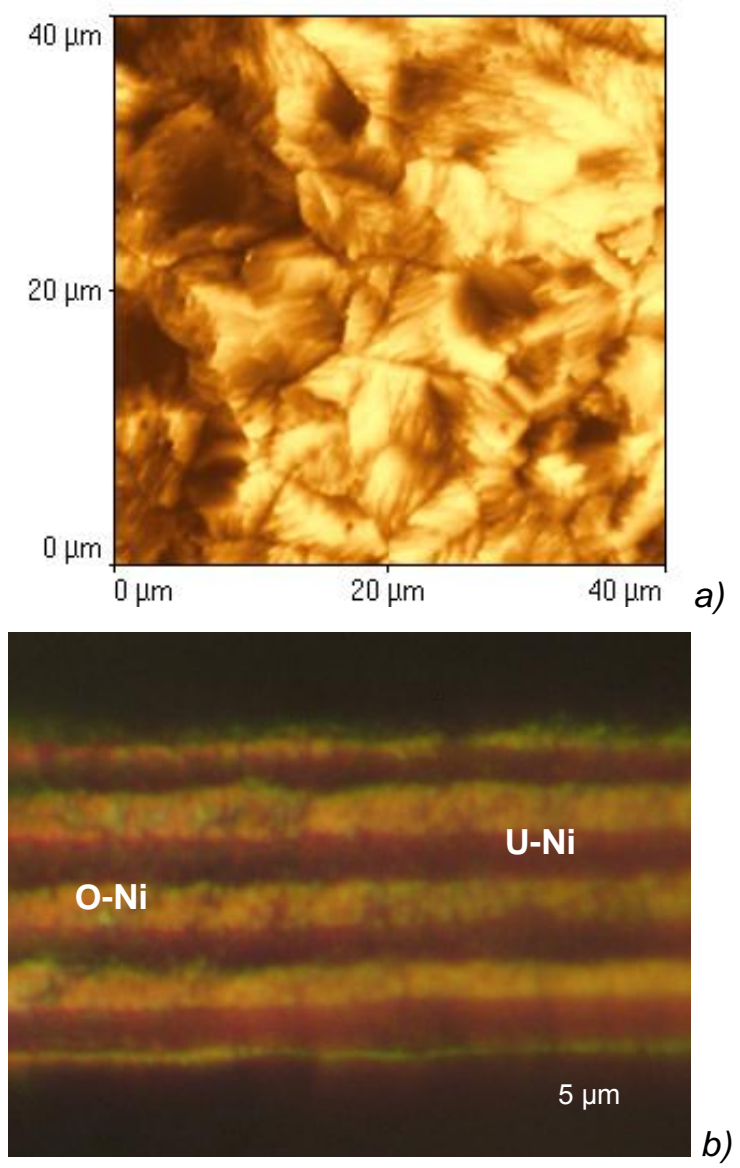

Figure 1. Optical image of revealed polycrystalline copper structure (a) and cross-section of multilayer U-Ni/O-Ni film, with layer thickness of $5 \mu \mathrm{m}$ (b)

Slika 1. Otkrivena struktura polikristalnog bakra (a) i poprečni presek višeslojnog U-Ni/O-Ni filma, sa debljinom sloja od $5 \mu \mathrm{m}$ (b), slike sa optičkog mikroskopa

For the analysis and comparison of composite hardness values, five samples were prepared. Two composite systems were consisted of monolayer $\mathrm{Ni}$ film electrochemically deposited on copper substrates without $(\mathrm{O}-\mathrm{Ni})$ and with $(\mathrm{U}-\mathrm{Ni})$ the ultrasonic agitation. The others were multilayer composite systems with alternately electrochemically deposited $\mathrm{O}-\mathrm{Ni} / \mathrm{U}-\mathrm{Ni}$ films with different layer thickness of $1 \mu \mathrm{m}, 500 \mathrm{~nm}$ and $250 \mathrm{~nm}$.

Change of the composite hardness $\left(H_{C}\right)$ of different composite ED Ni films/Cu supstrate systems with relative indentation depth, $h / t$ (indentation depth through film thickness), is shown on Fig.2. All of the ED Ni films are with the total thickness of $10 \mu \mathrm{m}$ and they were electrodeposited with $50 \mathrm{~mA} / \mathrm{cm}^{2}$ current density.

For the relative indentation depths between 0.1 and 1 , the microhardness response is of the composite system. It is confirmed that ultrasonicassisted electrodeposition leads to significant change in the film microstructure and properties. 
Higher values of the composite microhardness were obtained for the ultrasonic-assisted electrodeposited films in comparison with the ordinary electrodeposited films. Decreasing the layer thickness and increasing the number of interfaces lead to increasing the composite hardness of the multilayer film systems.

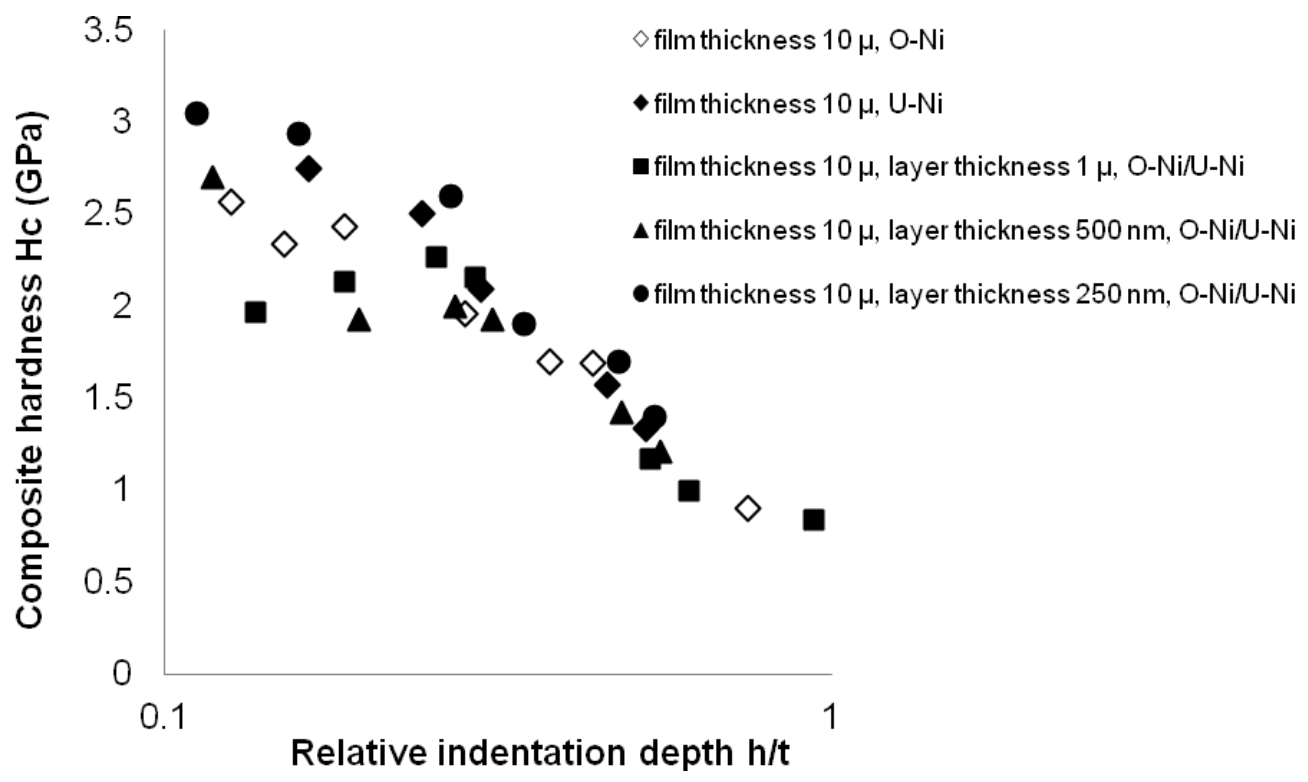

Figure 2. Variation in the composite hardness $H_{C}$, with relative indentation depth $(h / t)$, for $10 \mu$ m-thick ED Ni films on Cu supstrate

Slika 2. Varijacija kompozitne tvrdoće $H_{C}$, sa relativnom dubinom utiskivanja $(\mathrm{h} / \mathrm{t})$, za ED Ni filmove debljine $10 \mu \mathrm{m}$ na Cu supstratima

Experimental hardness measurements for chosen mono and multilayer systems were fitted with the composite model of Korsunsky (Fig. 3.). The curve-fit data produced from the model validation process are given in Table 2.

Table 2. The fitting results according to the composite model of Korsunsky for different composite systems of mono and multilayer electrodeposited Ni films on Cu substrates

Tabela 2. Rezultati fitovanja prema kompozitnom modelu Korsunskog za različite kompozitne sisteme formirane od jednoslojnih i višeslojnih ED filmova Ni na supstratima od $\mathrm{Cu}$

\begin{tabular}{|c|c|c|}
\hline $\mathrm{K}$ model & & Asymptotic standard error \\
\hline \multicolumn{3}{|c|}{ Ordinary electrodeposited monolayer Ni film O-Ni [16] } \\
\hline $\mathrm{H}_{\mathrm{F}}(\mathrm{GPa})$ & 2.68 & $\pm 0.11(4.1 \%)$ \\
\hline $\mathrm{k}^{\prime}$ & 0.0087 & $\pm 0.0017(20 \%)$ \\
\hline \multicolumn{3}{|c|}{ Ultrasound-assissted electrodeposited monolayer Ni film U-Ni $\left(10 \mu \mathrm{m}, 50 \mathrm{~mA} / \mathrm{cm}^{2}\right)$} \\
\hline $\mathrm{H}_{\mathrm{F}}(\mathrm{GPa})$ & 2.82 & $\pm 0.0 .28(10.05 \%)$ \\
\hline k' & 0.012 & $\pm 0.0043(34.17 \%)$ \\
\hline \multicolumn{3}{|c|}{ Multilayer O-Ni/U-Ni film (layer thickness $1 \mu \mathrm{m}$, total film thickness $10 \mu \mathrm{m}, 50 \mathrm{~mA} / \mathrm{cm}^{2}$ ) } \\
\hline $\mathrm{H}_{\mathrm{F}}(\mathrm{GPa})$ & 2.23 & $\pm 0.1113(4.98 \%)$ \\
\hline k' & 0.0091 & $\pm 0.001876(20.48 \%)$ \\
\hline \multicolumn{3}{|c|}{ Multilayer O-Ni/U-Ni film (layer thickness $500 \mathrm{~nm}$, total film thickness $10 \mu \mathrm{m}, 50 \mathrm{~mA} / \mathrm{cm}^{2}$ ) } \\
\hline $\mathrm{H}_{\mathrm{F}}(\mathrm{GPa})$ & 2.72 & $\pm 0.1956(7.47 \%)$ \\
\hline $\mathrm{k}^{\prime}$ & 0.011 & $\pm 0.0033(30.13 \%)$ \\
\hline \multicolumn{3}{|c|}{ Multilayer O-Ni/U-Ni film (layer thickness $250 \mathrm{~nm}$, total film thickness $10 \mu \mathrm{m}, 50 \mathrm{~mA} / \mathrm{cm}^{2}$ ) } \\
\hline $\mathrm{H}_{\mathrm{F}}(\mathrm{GPa})$ & 3.29 & $\pm 0.135(4.11 \%)$ \\
\hline $\mathrm{k}^{\prime}$ & 0.0169 & $\pm 0.1326(14.78 \%)$ \\
\hline
\end{tabular}


As shown in Table 2, the ultrasonic agitation increases the hardness of electrodeposited $\mathrm{Ni}$ films. Electrodeposition of multilayer films gives the possibility of designing the mechanical properties of composite systems by changing the thickness of the film layer. With decreasing the layer thickness within the film it is possible to achieve higher values of the film hardness.

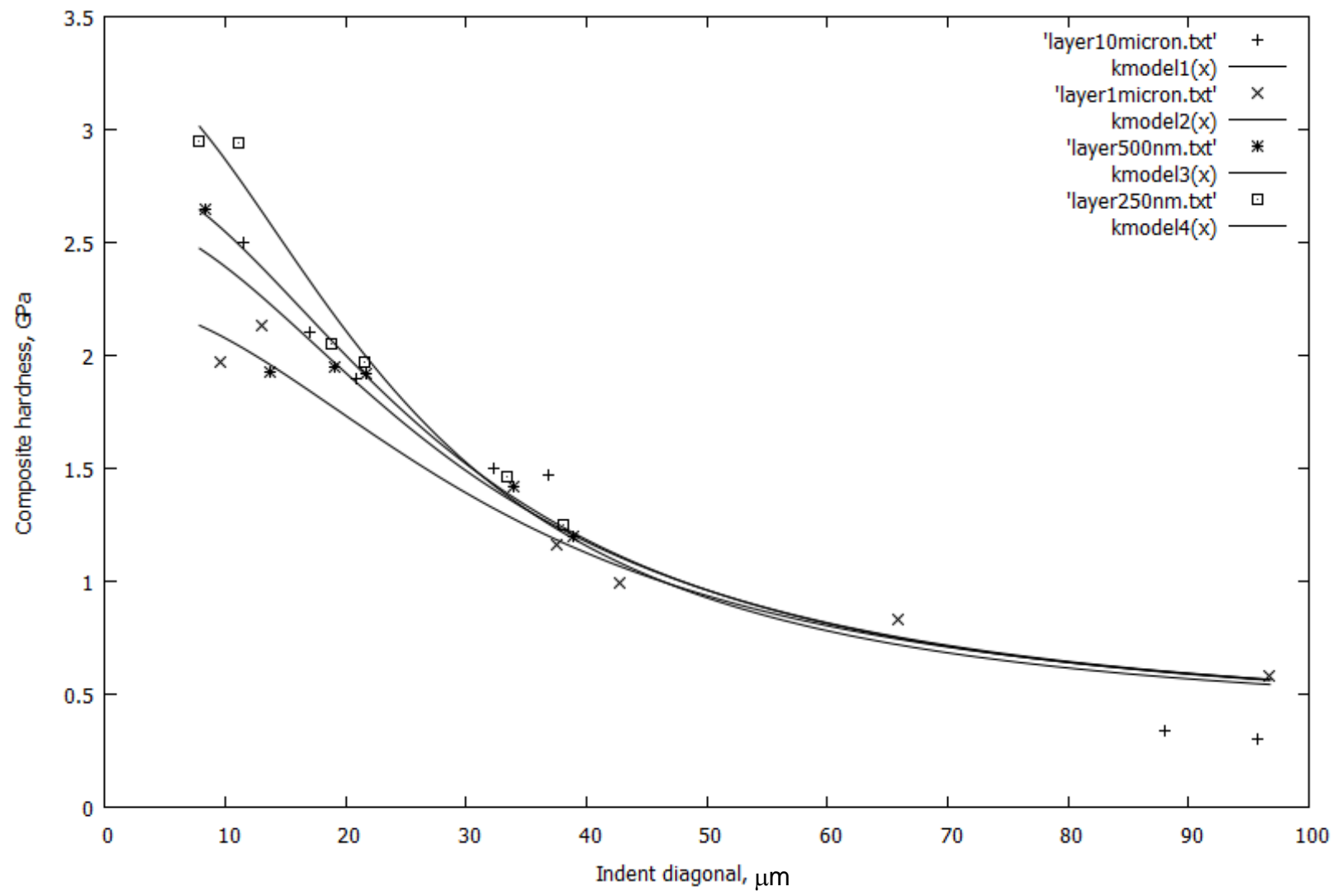

Figure 3. Experimental values of composite hardness, $H_{c}$, as a function of the indent diagonal length, $d$, for different Ni films on coled rolled Cu substrate. Films have the same thickness of $10 \mu \mathrm{m}$. Theoretical description according to the Korsunsky composite hardness model is indicated by lines on the diagram

Slika 3. Eksperimentalne vrednosti kompozitne tvrdoće, $H_{c}$, kao funkcije dužine dijagonale indenta, $d$, za različite filmove Ni na hladno valjanom $\mathrm{Cu}$ supstratu. Filmovi su iste debljine od $10 \mu \mathrm{m}$. Teorijski opis prema kompozitnom modelu tvrdoće Korsunskog je prikazan linijama na dijagramu

Together with the current density value, the ultrasonic agitation affects the film microstructure. The grain size of the U-Ni films is smaller than that of the O-Ni films and a small grain size can support a dislocation pileup. Also, a large number of the interfaces are considered to serve as a barrier to dislocations, obstruct dislocation movement between the layers.

\subsection{Adhesion evaluation}

A composite hardness model of Chen - Gao was employed to evaluate the adhesion of nickel films electrodeposited on copper substrates. The composite hardness of the film/ substrate system is given by Eq. (2) and in the form of Eq. (3) was used to calculate the critical reduced depth $b$. Indent diagonals on substrate and films surfaces were directly measured and $H_{S}$ and $H_{C}$ were calculated. The hardness of the ED Ni films was obtained as the result of applied Korsunsky model (Table 1.) and used in Eq. (3). In Fig.4 the results of calculating the critical reduced depth for different systems are shown.

Increasing adhesion corresponds to increasing values of the plastic deformation zone around the indentation. It can be expressed numerically by critical reduced depth $b$ (the ratio between the radius of the plastic zone beneath the indentation and the indentation depth). Therefore the critical reduced depth $b$ is parameter which is suitable for estimation the film adhesion. It is obvious that the microhardness difference decreases faster for a weaker adhesion when increasing the indentation load. 


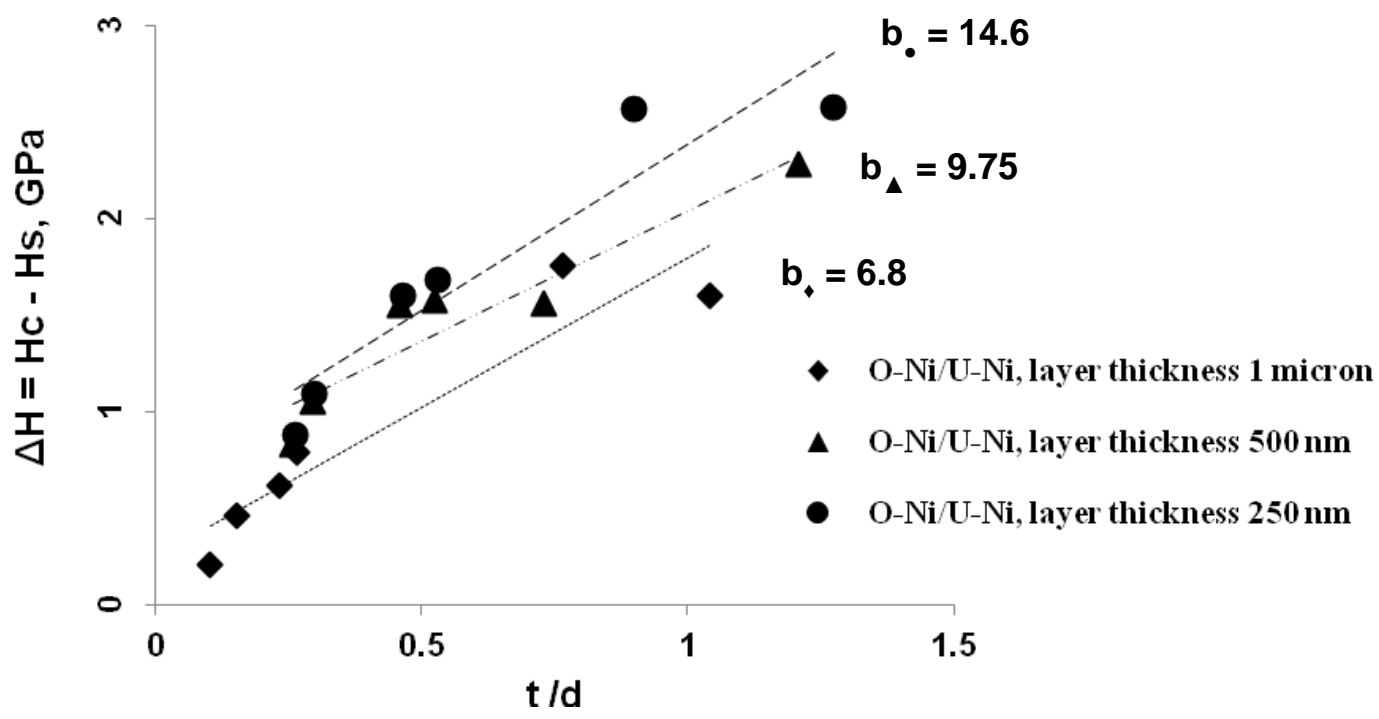

Figure 4. Hardness difference ( $\mathrm{Hc}-\mathrm{Hs}$ ) vs. ratio between the film thickness and the indentation diagonal $t / d$, for $10 \mu m$-thick multilayer ED O-Ni/U-Ni films on the copper substrates. The critical reduced depth $b$ for each system is given

Slika 4. Razlika tvrdoća (Hc-Hs) u zavisnosti od odnosa debljine filma i dijagonale indenta t/d, za višeslojne filmove ED O-Ni/U-Ni debljine $10 \mu \mathrm{m}$, na Cu supstratima. Kritična redukovana dubina b je data za svaki sistem

A bending test was employed for analysis the adhesion strength of the nickel films to the copper substrate [6]. Film hardness values and adhesion results expressed through critical reduced depth $b$ and critical cycle number, for different electrodeposited multilayer $\mathrm{O}-\mathrm{Ni} / \mathrm{U}-\mathrm{Ni}$ films on $\mathrm{Cu}$ substrates, are shown in Table 3.

Table 3. Comparison of results of the film hardness, critical reduced depth and adhesion test by bidirectional bend test for multilayer ED Ni films

Tabela 3. Poređenje rezultata tvrdoće filmova, kritične redukovane dubine i rezultata testa adhezije savijanjem u dva pravca za višeslojne ED Ni filmove

\begin{tabular}{|l|c|c|c|}
\hline \multicolumn{1}{|c|}{ Sample } & $\begin{array}{c}\text { Film } \\
\text { hardness, } \mathrm{H}_{\mathrm{F}}\end{array}$ & $\mathrm{b}$ & $\begin{array}{c}\text { Critical } \\
\text { cycle } \\
\text { number }\end{array}$ \\
\hline $\begin{array}{l}\text { O-Ni/U-Ni, layer } \\
\text { thickness 1 } \mu \mathrm{m}\end{array}$ & 2.23 & 6.8 & 34 \\
\hline $\begin{array}{l}\text { O-Ni/U-Ni, layer } \\
\text { thickness 500 nm }\end{array}$ & 2.72 & 9.75 & 41 \\
\hline $\begin{array}{l}\text { O-Ni/U-Ni, layer } \\
\text { thickness 250 nm }\end{array}$ & 3.29 & 14.6 & 49 \\
\hline
\end{tabular}

It can be seen that decreasing the layer thickness from $1 \mu \mathrm{m}$ down to $250 \mathrm{~nm}$ leads to higher values of film hardness and much better adhesion performance compared with the ordinary nickel films. Using of multilayer films is effective way to release the stress across the interface of $\mathrm{Ni}$ films and the substrate. The distribution of stress at the interface is an important factor governing the adhesion of the film to the substrate.

\section{CONCLUSION}

Different composite systems of mono and multilayer $\mathrm{Ni}$ films electrodeposited on copper substrates were prepared and investigated. Multilayer Ni film structure was accomplished by alternation of ordinary and ultrasonic-assisted electrodeposition. Mechanical properties of composite systems depend on the microstructure of the substrate and of the film. The ultrasonic agitation changes the microstructure of the $\mathrm{Ni}$ layers because the grains of the U-Ni layer grow preferentially in the manner parallel to the substrate surface. Higher values of the composite and film microhardness were obtained for the ultrasonicassisted electrodeposited films in comparison with the ordinary electrodeposited films. Decreasing the layer thickness and increasing the number of interfaces lead to increasing the hardness of the multilayer film systems and better adhesion properties expressed through increased values of the critical reduced depth and critical cycle number.

\section{Acknowledgements}

This work was funded by Republic of Serbia Ministry of Education, Science and Technological Development through the projects TR 32008, TR 34011 and TR 34019. 


\section{REFERENCES}

[1] F.Ebrahimi, G.R.Bourne, M.S.Kelly, T.E.Matthews (1999) Mechanical properties of nanocrystalline nickel produced by electrodeposition, Nanostructured materials, 11(3), 343-350.

[2] T.Fritz, W.Mokwa, U.Schnakenberg (2001) Material characterisation of electroplated nickel structures for microsystem technology, Electrochemica Acta, 47, 55-60.

[3] M.Datta, D.Landolt (2000) Fundamental aspects and applications of electrochemical microfabrication, Electrochimica Acta, 45, 2535-2543.

[4] A.Rasmussen et al. (2006) Microstructure and thermal stability of nickel layers electrodeposited from an additive-free sulphamate-based electrolyte, Surf. \& Coat. Technol., 200, 6037-6046.

[5] C.T.Walker, R.Walker (1973) Effect of ultrasonic agitation on some properties of electrodeposits, Electrodeposition and Surface treatment, 1, 457469.

[6] R.Cui, Y.He, Z.Yu, W.Shu, J.Du (2010) Preparation and Characterization of Ultrasonic Electrodeposited Copper Coating, 11th International Conference on Electronic Packaging Technology \& High Density Packaging, China.

[7] Y.Niu, J.Wei, Y.Yang, J.Hu, Z.Yu (2012) Influence of microstructure on the wear mechanism of multilayered $\mathrm{Ni}$ coating deposited by ultrasoundassisted electrodeposition, Surface \& Coatings Technology, 210, 21-27.

[8] Z.Yu, Y.Zhu, Y.Niu, Y.Yang, J.Wei, W.Ding (2013) Preparation and adhesion performance of multilayered $\mathrm{Ni}$ coatings deposited by ultrasonicassisted electroplating, Journal of adhesion asience and technology, 27 (2), 136-142.

[9] R.C.Cammarata (1994) Mechanical properties of nanocomposite thin films, Thin solid Films, 240, 8287.

[10] Y.Kaneko, Y.Mizuta, Y.Nishijima, S.Hashimoto (2005) Vickers hardness and deformation of $\mathrm{Ni} / \mathrm{Cu}$ nano-multilayers electrodeposited on copper substrates, Journal of material science, 40, 3231 3236.

[11] L.Magagnin, R.Maboudian, C.Carraro (2003) Adhesion evaluation of immersion plating copper films on silicon by microindentation measurements, Thin solid films, 434, 100-105.

[12] A.M.Korsunsky, M.R.McGurk, S.J.Bull, T.F.Page (1998) On the hardness of coated systems, Surf. \& Coat. Technol., 99, 171-183.

[13] M.Chen, J.Gao (2000) The adhesion of copper films coated on silicon and glass substrates, Modern Physics Letters B, 14 (3), 103-108.

[14] H.S.Rawdon, M.G.Lorentz (1921) Metallographic Etching Reagents:Il.For copper alloys, nickel and the alpha alloys of nickel, Scientific papers of the bureau of standards, 17, 345-351.

[15] H.Li, R.C.Bradt (1993) The microhardness indentation load/size effect in rutile and cassiterite single crystals, J. Mater. Sci., 28, 917-924.

[16] J.Lamovec, V.Jović, D.Randjelovic, R.Aleksic, V. Radojevic (2008) Analysis of the composite and film hardness of electrodeposited nickel coatings on different substrates, Thin Solid Films, 516, 86-96.

\title{
IZVOD
}

\section{DOBIJANJE I KARAKTERIZACIJA VIŠESLOJNIH TANKIH FILMOVA NIKLA ELEKTRODEPONOVANIH UZ POMOĆ ULTRAZVUČNOG MEŠANJA}

\begin{abstract}
Višeslojne kompozitne strukture su sačinjene od elektrodeponovanih filmova Ni na supstratima od polikristalnog bakra uz pomoć ultrazvučnog mešanja. Naizmenična elektrodepozicija slojeva Ni bez i uz pomoć ultrazvučnog mešanja omogućila je formiranje laminatnih filmova. Adhezija i tvrdoća su okarakterisane ispitivanjem na savijanje u dva pravca i Vikersovim testom mikrotvrdoće sa različitim opterećenjima. Zavisnost kompozitne mikrotvrdoće $i$ adhezije filma od debljine sloja je ispitana. Potvrđeno je da veliki broj međuslojnih granica doprinosi povećanju tvrdoće $i$ jačine kompozita. Za obradu eksperimentalnih podataka su odabrani i primenjeni model Korsunskog za izračunavanje tvrdoće filma i model Čen-Gao za procenu adhezije filma. U poređenju sa filmovima Ni elektrodeponovanim na konvencionalan način, mehanička svojstva filmova elektrodeponovanih u prisustvu uzltrazvuka su poboljšana. Vrednosti mikrotvrdoće i adhezije su povećane uvođenjem ultrazvuka i smanjenjem debljine pojedinačnog sloja Ni u filmu.
\end{abstract}

Ključne reči: kompozitna tvrdoća, Ni elektrodepozicija, ultrazvučno mešanje, adhezija, višeslojni filmovi.

Naučni rad

Rad primljen: 29. 01.2018.

Rad prihvacen: 25. 02. 2018.

Rad je dostupan na sajtu: www.idk.org.rs/casopis

(C) 2018 Authors. Published by Engineering Society for Corrosion. This article is an open access article distributed under the terms and conditions of the Creative Commons Attribution 4.0 International license (https://creativecommons.org/licenses/by/4.0/) 